軸先端の改良で誤差原因はなくなったが，輪郭部をトレ ースするのが手動であるため正確にトレースするととは 殆んど不可能であった，例えば画像倍率が30\% 50\%の 縮少率で入力すると，平均奉物大に換算して $1.7 \sim 1.00$ $\mathrm{mm}$ 以内の誤差があった。

\section{CT 画像を利用した治療計画（第II報）}

大阮学災病院放射線科治療部 ○磯部義秀・尾崎”新

〔目的〕 2 次元 $\mathrm{CT}$ 画像から 3 次元王体表示システム の試みをした。 3 次元画像では生体の空間的配置の把握 を容易なすのとし治療計画利用に扮して有益な情報を得 るととが出来た。

〔結果】 (1) Therac III Minicomputer 使って2次 元画像加 3 次元立体表示の soft wear 開発した。 (2) ライトスルー方式で 3 次元画像内にカーソルを表示とれ を任意の位置に siftさせ病巣深度や照射角度が計算出来 る. (3)病坚を中心とした立体的な照射野表示又は体積 計算が出来るので治療計画がやりやすくなった. (4) 照 射野内における正常組織の関心領域を入力するととによ りシャドートレ上での幾何学的な倍率隹計算した $\mathrm{Pb}$-ブ ロック図型を $\mathrm{X}-\mathrm{Y}$ plotter 亿 plot 出来る.

\section{8． CT 情報の放射線治療計画への応用}

自治医科大学附属病院中央放射線部

○石塚二郎・三沢一郎

增田之み子・伊藤えい子

CT 情報を利用し，肺に対する治療計画及び照射線 量 の補正方法について, 東芝 TCT-60A, アートロニクス PC-12コシピュータを使用して検討を行なった。各部の 輪郭は，CT 像を写真俍り，それよりコンピュータへ 大力した。密度は，各位置におけるCT 值を ROI 機能 により読み，あらかじめ求めておいた CT 值之密度の関 係より，密度に変換して使用した，照射線量の補正は， PC-12 のプロフィール機能を利用した.

今回の方法では， CT 值の安定性，コンピュータの入 力誤差, 異質計画の誤差等, また多少の問題はあるが， 從来よりも適切な治療計画加，個々の患者に対して行な え，一応日常の臨床汇応用でさると考えられる。

\section{CT 像の治療計画への利用 (電子密度の測定)}

信州大学医学部附属病院中央放射線部

○知野今朝人 : 丸山 清 : 淹沢正臣

竹村克人・横山佳代子・小口，虑

Body CT 像加ら求好た電子密度を利用し，線量計算 する場合の基礎的な問題点について検討した。

(1) CT 值加ら直線近似して求めた電子密度を 線量計
算に利用しても，実效原子番号が $6.03 \sim 8.43$ の範囲内に 於て臨床的にほぼ許容されると思われた。

(2) 線量相対誤差を $2 \%$ 以下にするためのCT 像のマ トリックスサイズは， $80 \times 80$ 以上すなわち 1 絵素幅で 5 $\mathrm{mm}$ の精度が必要であった。

(3) 腹部軟部組織, 腰椎及び肺野に於て, 相対電子密 度として平均值 $(1.0,1.15,0.30)$ を使用した場合, 線 量相対誤差は $1 \%$ 以下であった。

\section{座長集約}

CT の出現は，診断領域に多大なインパクトを与えた か，同様に放射線治療に関する分野で屯，治療計画の質 的変革をむたらさんとしていると言っても過言ではなか ろう. 即ち CT の持つ情報には，体の外翰郭は言うに及 ‘ばず蔵器, 腫瘍などの明膫な輪郭情報と, 画素ごとの密 度情報に含九でいる。しか子それらは三㳄元の搪がりの データとして持っているため，障害を最少とした木目細 かな，理想的プランニングの可能性を示している．今度 の発表においても，CT 情報を本格的に利用し治療の精 度を高めようとする，質の高い報告が見られ，今後の発 展が期待される。

64. 荒井らは，以前から頭頸部の治潦に対し，シェル （固定具）を用い再現性を保持するととを報告している が，今回はさらにシェル上で，CT，の横断面位置を対比 させ，その輸郭情報を利用した線密な治燎計画の報告を 行っている：特に三次元的プランニングを実用的俘行っ ている点に注目したい.

65. 三塩らは, 線量計算に必要な輪郭情報を CT のデ 一夕から自動的に抽出したむので,アルゴリズムに新し さがあるままた，CRTなどのアナログ機器は精度，.安 定性に構造的な問題があり，サイズの精度維持は困難で ある. そのため CRT 像のコピーに直接利用するととは 危険だとして，プロッタに打出した輪郭を使用した方が よりと報告している。

66. 磯部らは，CT 像记線量分布を superimpose した 6ので, 正確な解剖学的構造との対比が容易になうたと し，さらにサイズの精度についてす検討しているが, 臨 床的には無視できる詋差であったとしている。

67. 同じく磯部らは，CT から得られる輸郭線の 組合 せによる三次元表示について報告している。体内構造の 空間配置の把握, target volume などの容積計算が 容易 になったとのことであった。陰線除去などの改良を加え， より芫易い表示にするととあに，三次元線量分布を重ね

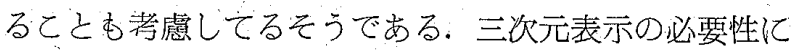

